DOI: $10.2478 / \mathrm{v} 10129-010-0005-7$

\author{
Anna Czubaszek \\ Department of Fruit, Vegetables and Grain Technology, Wrocław University of Environmental \\ and Life Sciences, 50-375 Wrocław, ul. C.K.Norwida 25, Poland, e-mail: anna.czubaszek@up.wroc.pl

\section{THE EFFECTS OF GENOTYPE AND ENVIRONMENT ON SELECTED TRAITS OF OAT GRAIN AND FLOUR}

\begin{abstract}
The purpose of the investigation was to study the effects of variety properties of oat cultivars and environmental conditions on physical traits and chemical composition of grain and flour. Nine oat cultivars had been grown in the experimental plots (stations) located in two experimental stations in Jelenia Góra and Bobrowniki. The samples were collected in two harvest years. As it has been found, the genetic factors affected physical traits of the grain. The chemical composition of oat grain depended to a large extent on the weather conditions during the growing season. The genetic factors affected only total protein content of the oat grain. The grain of the oat cultivars under investigation was high in total protein but low in starch. Its proteolytic and amylolytic activities were on average levels. Total protein and pentosan content as well as proteolytic activity of the oat flour were lower than those of grain, but starch content and the falling number were higher.
\end{abstract}

Key words: chemical composition, environments, flour, grain, oat varieties, physical traits

\title{
INTRODUCTION
}

In Poland, oats production is high (5.6\% of world production). The sowing area in 2007 reached 584300 hectares, with the crops amounting to 1462000 tones. But their use in food industries is limited to oat flakes production. On a global scale, about $20 \%$ of oats harvested is destined for food products manufacturing and there is a wide range of oat food products available on the market (GUS 2009). A growing interest in oat food products manufacturing is the consequence of the results reported by researchers, which show that this cereal exhibits exceptional physiological and nutritional properties, unique flavour. Moreover, it can be a valuable dietetic and healthy ingredient in many food products, due to specific properties of

Communicated by Henryk J. Czembor 
its soluble fiber and protein fractions (Lapveteläinen et al. 2001, Ötles and Cagindi 2006).

The use of oat grain depends on its agronomic properties, physical traits and chemical composition (Peterson et al. 2005). Oat grain destined for the food industry must reach specified standards, which means that only the grain that is healthy, uniform in size, well-filled, with no discoloration, two-spikelet kernels, high in protein and soluble fiber ( $\beta$-glucan), but low in fat is acceptable (Glen 2004). High nutrition value of the oat protein is widely recognized with lysine contents higher than in case of other grains (Ma 1983). Numerous researches were dedicated to the properties and significance of the fibre in oat grain (Peltonen-Sainio and Topi-Hulmi 2004). Due to technological purposes, other ingredients of the grain are also significant. Michniewicz (1995) indicates important role played by pentosans in grain technology. Those are compounds that significantly influence rheological properties and water absorption. Such features may be of great significance while using oat flour for bakery purposes. The possibility to use the grain and its products in order to obtain various kinds of food products is also determined by the activity levels of enzymes such as amylase and proteases (Dojczew and Sobczyk 2007, Konopka et al. 2004).

Doehlert and Mc Mullen (2000) reported that physical traits of oat grain were, to a large extent, dependent on environmental factors and genotype as well as interactions between them. Later reports (Peterson et al. 2005, Walens 2003) showed that depending on environmental factors and cultivars used, the grain exhibited varied chemical composition and milling properties.

Relatively little information can be found on the impact of the environment and the genotype on technological properties of oat grain and flour. For this reason, the authors of the present investigation have made an attempt to determine the relation between significant differences in physical traits of oat grain and the content of some chemical constituents present in oat grain and flour in relation to the cultivars and environmental factors.

\begin{tabular}{|c|c|c|c|c|c|c|}
\hline \multicolumn{7}{|c|}{ Crop and soil conditions of trials } \\
\hline \multirow{2}{*}{ Location } & \multirow{2}{*}{$\begin{array}{l}\text { Year of } \\
\text { harvest }\end{array}$} & \multirow{2}{*}{$\begin{array}{l}\text { Land capability } \\
\text { complex }\end{array}$} & \multirow{2}{*}{ Previous crops } & \multicolumn{3}{|c|}{ Rate of fertilization $[\mathrm{kg} \cdot \times$ ha- 1$]$} \\
\hline & & & & $\mathrm{N}$ & $\mathrm{P}$ & $\mathrm{K}$ \\
\hline \multirow{2}{*}{ Jelenia Góra } & 1997 & \multirow{2}{*}{$\begin{array}{l}\text { mountain } \\
\text { cereal }\end{array}$} & buckwheat & 74 & 80 & 80 \\
\hline & 1998 & & winter wheat & 60 & 70 & 70 \\
\hline \multirow{2}{*}{ Bobrowniki } & 1997 & \multirow{2}{*}{$\begin{array}{l}\text { very good } \\
\text { rye }\end{array}$} & potatoe & 80 & 80 & 80 \\
\hline & 1998 & & potatoe & 80 & 80 & 80 \\
\hline
\end{tabular}




\section{MATERIALS AND METHODS}

\section{Materials}

The material consisted of grain of 9 oat cultivars (Bajka, Dragon, German, Góral, Jawor, Kwant, Komes, Skrzat, Sławko). The oat grain was obtained from two experimental stations (located in Jelenia Góra and Bobrowniki), harvested in 1997 and 1998 (Table 1). The field samples were implemented on soils of a mountain cereal complex (Jelenia Góra) and a fine rye complex (Bobrowniki). In Jelenia Góra, oat was grown after buckwheat (1997) and winter wheat (1998), whereas in Bobrowniki it was grown after potatoes, fertilized with typical fertilizer rates. The sowing period took started at the end of March or at the beginning of April, with the harvest taking place at the end of July and the beginning of August. The agrotechnical treatments were in compliance with those recommended for oat plants (Sułek et al. 2001).

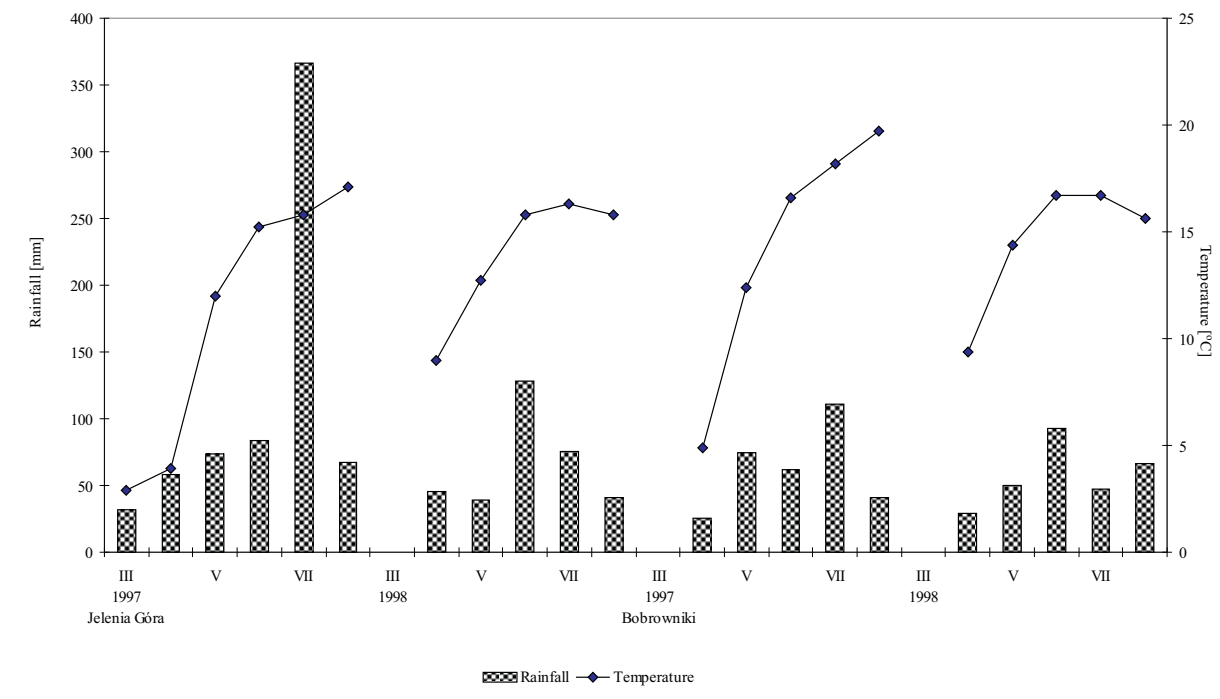

Fig. 1. Weather conditions in the areas where the experiments were led

In 1997 shortly after sowing, the temperatures in April both in Jelenia Góra and Bobrowniki were below average (Fig.1). In July 1997, Jelenia Góra suffered from severe rainfalls which caused considerable plants lodging. Nevertheless, the precipitation level in Bobrowniki in 1997 was appropriate considering oat plant growth. In 1998, the temperature range in the two locations was close to average for this part of Poland, and the distribution of rainfalls was favourable for oat plant growth.

\section{Methods}

The hectoliter weight was determined according to PN-ISO 7971-2:1998. The 1000-grain weight was obtained by counting and weighing four sam- 
ples of 100 kernels randomly chosen after removal of broken grains. Share of grain of different thickness was qualified using mechanical sorter (sieves with openings $25 \mathrm{~mm} \times 2.8,2.5$ and $2.2 \mathrm{~mm}$ ). Content of hull was estimated after hand dehulling of $10 \mathrm{~g}$ grain sample and qualification of proportional part of hull in relation to mass of the whole hulled grain. The yield of oat flour and bran was determined using a Quadrumat Junior laboratory mill (Brabender). Milling was performed after husking in an OL-1 laboratory husker (PZZ - ZRM Co. Szczytna) and tempering (to 11\% moisture content) for 24 hours. The flour was screened through and the bran was running out of the sieve (mesh size of $295 \mu \mathrm{m}$ ).

Prior to chemical analysis, groat oat had been ground in a laboratory hammer mills type W-Ż 1 (Sadkiewicz Instruments ZBPP Bydgoszcz). The determinations included the chemical composition of both the grain and the flour. Total protein content was determined using Kjeldahl method $(\mathrm{N} \times$ 6.25). Starch content was determined using amyloglucosidase as described by Lue et al. (1991). Soluble and total pentosans were determined, using anilin method, as described by Subda (1984 b). This method allows an acid hydrolysis of pentosans present in the sample and colorimetric determination of xylose using aniline acetate. The results were compared with the xylose standard curve. The quantity of insoluble pentosans was estimated basing on the difference between the content of total and soluble pentosans. The activity of proteolytic enzymes was measured using the modified method of Ayre-Anderson (Subda 1984 a). The quantity of tyrosin $\mu$ mols obtained from $1 \mathrm{~g}$ of flour during $1 \mathrm{~min}$ was considered a unit of activity. The falling number was also determined (PN-ISO 3093:1996). All analysis was carried out directly after the harvest.

\section{Statistical Analysis}

The data obtained in the study was analyzed using a three-factor analysis of variance (cultivar, location and year). The basis for the multifactoral variation analysis was fragmentation of the total variation into ingredients corresponding to the variability caused by the subsequent factors and interactions between them and residue variability. The essence of the analysis was the comparison of variations obtained using F-Snedecor test on the assumption that the variables are of Gaussian distribution or close to normal distribution. In own, original research in order to prove the hypothesis the role of error was attributed to interactions between the three factors. The significance of differences between means was compared by Duncan's multiple range tests $(\mathrm{P} \geq 0.95)$. The statistical calculations were made using the ANOVA package from Statgraphics 5.0 software. 
Table 2

Variation components for qualitative traits of oat grain and flour -percentage in total variation

\begin{tabular}{|c|c|c|c|c|c|c|c|c|}
\hline \multirow{2}{*}{\multicolumn{2}{|c|}{$\begin{array}{l}\text { Source of variation } \rightarrow \\
\text { Trait } \downarrow\end{array}$}} & \multirow{2}{*}{\multicolumn{2}{|c|}{ Cultivars (C) Location (L) }} & \multirow{2}{*}{ Year $(Y)$} & \multicolumn{4}{|c|}{ Interaction } \\
\hline & & & & & $\mathrm{C} \times \mathrm{L}$ & $\mathrm{C} \times \mathrm{Y}$ & $\mathrm{L} \times \mathrm{Y}$ & $\mathrm{C} \times \mathrm{L} \times \mathrm{Y}$ \\
\hline \multicolumn{2}{|l|}{ Hectoliter weight } & 2.84 & $9.57 *$ & $19.26^{*}$ & 0.45 & 0.44 & $66.09 *$ & 1.34 \\
\hline \multicolumn{2}{|c|}{ 1000-kernel weight } & $69.18^{*}$ & $13.80^{*}$ & $10.86^{*}$ & 0.92 & 0.32 & $4.60 *$ & 0.32 \\
\hline \multicolumn{2}{|l|}{ Hull content } & $17.92 *$ & 3.59 & 1.76 & 3.00 & 2.31 & $69.66^{*}$ & 1.76 \\
\hline \multicolumn{9}{|c|}{ Share of grain of thicknesses } \\
\hline \multicolumn{2}{|l|}{$>2.8 \mathrm{~mm}$} & $75.83^{*}$ & 1.39 & 0.02 & 1.47 & 5.63 & 0.13 & 15.53 \\
\hline \multicolumn{2}{|l|}{$2.5-2.8 \mathrm{~mm}$} & $10.09^{*}$ & $40.74 *$ & $40.86^{*}$ & 1.43 & 1.12 & 4.43 & 1.32 \\
\hline \multicolumn{2}{|l|}{$2.2-2.5 \mathrm{~mm}$} & $16.31 *$ & $40.99 *$ & $33.12 *$ & $2.33 *$ & 1.78 & $4.81 *$ & 0.67 \\
\hline \multicolumn{2}{|l|}{$<2.2 \mathrm{~mm}$} & $7.45^{*}$ & $19.00^{*}$ & $64.63 *$ & 1.13 & 2.16 & 4.53 & 1.09 \\
\hline \multicolumn{2}{|l|}{ Flour yield } & $61.03 *$ & 9.86 & 0.98 & 7.74 & 6.97 & 4.66 & 8.84 \\
\hline \multicolumn{2}{|l|}{ Bran yield } & $61.01 *$ & 9.86 & 0.98 & 7.74 & 7.01 & 4.66 & 8.84 \\
\hline \multirow{2}{*}{$\begin{array}{l}\text { Total protein } \\
\text { content }\end{array}$} & Grain & $2.09 *$ & $2.67 *$ & $47.65^{*}$ & $1.10^{*}$ & 0.24 & $45.98^{*}$ & 0.27 \\
\hline & Flour & 4.66 & 7.92 & $57.19^{*}$ & 1.05 & 0.29 & $27.32 *$ & 1.57 \\
\hline \multirow{2}{*}{$\begin{array}{l}\text { Proteolytic } \\
\text { activity }\end{array}$} & Grain & 8.63 & 1.26 & $64.42 *$ & 10.53 & 4.63 & 0.21 & 10.32 \\
\hline & Flour & 3.12 & 6.58 & $82.15^{*}$ & 3.47 & 2.77 & 0.00 & 1.91 \\
\hline \multirow{2}{*}{ Starch content } & Grain & 2.71 & $77.33^{*}$ & 7.94 & 1.85 & 3.06 & 5.38 & 1.73 \\
\hline & Flour & 1.33 & $9.58 *$ & $77.61^{*}$ & 0.66 & 1.09 & $9.00 *$ & 0.73 \\
\hline \multicolumn{9}{|c|}{ Pentosans content } \\
\hline \multirow{2}{*}{ Soluble } & Grain & 5.41 & 0.00 & $62.16^{*}$ & 5.41 & 8.11 & 16.22 & 2.70 \\
\hline & Flour & 1.48 & $16.25^{*}$ & $33.97 *$ & 0.00 & 0.00 & $47.27 *$ & 1.03 \\
\hline \multirow{2}{*}{ Insoluble } & Grain & 1.55 & $5.53 *$ & $83.58 *$ & 0.52 & 0.62 & $7.37 *$ & 0.83 \\
\hline & Flour & 0.84 & 0.00 & $97.47^{*}$ & 0.42 & 0.84 & 0.00 & 0.42 \\
\hline \multirow{2}{*}{ Total } & Grain & 1.36 & $5.11 *$ & $86.35^{*}$ & 0.50 & 0.53 & $5.52 *$ & 0.62 \\
\hline & Flour & 0.69 & 0.00 & $96.54^{*}$ & 0.35 & 0.69 & 1.38 & 0.35 \\
\hline \multirow{2}{*}{ Falling number } & Grain & 2.52 & $23.30^{*}$ & $67.64 *$ & 2.90 & 1.73 & 0.19 & 1.73 \\
\hline & Flour & 3.71 & 0.24 & $75.20 *$ & 1.09 & 2.04 & $16.29 *$ & 1.44 \\
\hline
\end{tabular}

* _ significant variability at $\mathrm{P} \geq 0.95$ 


\section{RESULTS AND DISCUSSION}

The analysis of variance showed that the hectoliter weight depended exclusively on the environmental factors (location of the experiments and harvest year), and the greatest contribution to total variation was found with a location-year interaction (Table 2). This interaction also influenced the hull content to a large extent. Besides, the hectoliter weight also depended on the oat cultivar. 1000-kernel weight was both cultivar- and environment-dependent, but contribution of the genetic factor was greater $(69.18 \%)$ than that of the environmental impact $(13.80 \%$ - location and $10.86 \%$ - year). The percentage of oat grain, the thickness of which was $>2.8 \mathrm{~mm}$ as well as flour and bran yields were mainly cultivar-dependent. It was found that the quantity of oat kernels $<2.2 \mathrm{~mm}$ predominantly correlated with the weather conditions prevailing throughout the growing season (year variance). The cultivar-location interaction had an impact on the percentage of oat kernels within the thickness range of 2.2-2.5 $\mathrm{mm}$ and on protein content of oat grain. Besides, the location-year interactions affected the physical traits (hectoliter weight, 1000-kernel weight and hull content) and total protein content of oat grain and flour, starch and soluble pentosans of flour as well as insoluble and total pentosans of grain.

The content of the constituents present in the oat grain and flour was primarily dependent on changeability of the conditions prevailing in a given location and harvest year. Only total protein content of the grain was cultivar- and environmental-dependent, but the participation of the year variability $(47.65 \%$ - grain, $57.19 \%$ - flour) in the total variabilty was significanlty higher than that of the location $(2.67 \%)$ and cultivar $(2.09 \%)$ variables. Starch content of oat grain was mainly affected by the location of the plot $(77.33 \%)$, while starch content of oat flour revealed the greatest differences, depending on the harvest year (77.61\%). The highest contribution to the total variance observed within the other chemical characteristics of both oat grain and flour was found within the years' variable.

The results obtained in the present study are in accordance with those obtained in earlier studies on the quality of oat grain, which also showed that the quality of oat grain depended on the genetic factors and environmental conditions throughout the growing season (Peterson et al. 2005, Doehlert and McMullen 2000, Rhymer et al. 2005).

As reported in original research, the lack of significant influence of interaction between both the cultivars and the location and the cultivars and the crop year (Table 2) on most of the oat grain and flour features examined indicates their considerable stability in the aspect of habitat and years assessed. Nevertheless, the results obtained by Doehlert et al. (2001) and Peterson et al. (2005) indicate significant influence of interactions genotype $\mathrm{x}$ environment (location and year) on features such as: grain yield, ker- 
Physical traits of grain of oat for cultivar, location and years

\begin{tabular}{|c|c|c|c|c|c|c|c|}
\hline Trait $\rightarrow$ & \multirow{2}{*}{$\begin{array}{l}\text { Hectoliter } \\
\text { weight } \\
{[\mathrm{kg} \times \cdot \mathrm{hl}-1]}\end{array}$} & \multirow{2}{*}{$\begin{array}{c}1000 \text { - kernel } \\
\text { weight } \\
{[\mathrm{g}]}\end{array}$} & \multicolumn{4}{|c|}{ Share of grain of thicknes[\%] } & \multirow{2}{*}{$\begin{array}{c}\text { Hull } \\
\text { content } \\
{[\%]}\end{array}$} \\
\hline$\downarrow$ Factor & & & $>2.8 \mathrm{~mm}$ & $2.5-2.8 \mathrm{~mm}$ & $2.2-2.5 \mathrm{~mm}$ & $<2.2 \mathrm{~mm}$ & \\
\hline \multicolumn{8}{|c|}{ Cultivars } \\
\hline Bajka & $54.1 \mathrm{a}$ & $42.3 \mathrm{~b}$ & $23.3 \mathrm{~b}$ & $55.3 \mathrm{ab}$ & $18.7 \mathrm{de}$ & $2.7 \mathrm{bcd}$ & $23.2 \mathrm{bc}$ \\
\hline Dragon & $53.3 \mathrm{a}$ & $39.1 \mathrm{~cd}$ & $13.3 \mathrm{~b}$ & $61.3 \mathrm{a}$ & $22.8 \mathrm{~cd}$ & $2.7 \mathrm{bcd}$ & $22.9 \mathrm{bc}$ \\
\hline German & $54.0 \mathrm{a}$ & $40.4 \mathrm{c}$ & $22.4 \mathrm{~b}$ & $49.6 \mathrm{abc}$ & $25.9 \mathrm{bc}$ & $1.9 \mathrm{~cd}$ & $24.0 \mathrm{~b}$ \\
\hline Góral & $53.0 \mathrm{a}$ & $36.0 \mathrm{e}$ & $25.9 \mathrm{~b}$ & $43.7 \mathrm{bc}$ & $26.4 \mathrm{bc}$ & $3.9 \mathrm{bc}$ & $25.8 \mathrm{a}$ \\
\hline Jawor & $51.6 \mathrm{a}$ & $36.9 \mathrm{e}$ & $15.5 \mathrm{~b}$ & $49.5 \mathrm{abc}$ & $31.4 \mathrm{~b}$ & $3.7 \mathrm{bc}$ & $23.7 \mathrm{bc}$ \\
\hline Komes & $51.0 \mathrm{a}$ & $37.6 \mathrm{de}$ & $15.4 \mathrm{~b}$ & $30.2 \mathrm{~d}$ & $47.1 \mathrm{a}$ & $7.4 \mathrm{a}$ & $25.8 \mathrm{a}$ \\
\hline Kwant & $53.2 \mathrm{a}$ & $37.5 \mathrm{de}$ & $17.1 \mathrm{~b}$ & $52.5 \mathrm{abc}$ & $26.5 \mathrm{bc}$ & $3.8 \mathrm{bc}$ & $22.0 \mathrm{de}$ \\
\hline Skrzat & $50.6 \mathrm{a}$ & $36.5 \mathrm{e}$ & $13.6 \mathrm{~b}$ & $54.3 \mathrm{abc}$ & $27.6 \mathrm{bc}$ & $4.5 \mathrm{~b}$ & $23.6 \mathrm{bc}$ \\
\hline Sławko & $52.8 \mathrm{a}$ & $44.6 \mathrm{a}$ & $43.2 \mathrm{a}$ & $42.7 \mathrm{c}$ & $13.0 \mathrm{e}$ & $1.1 \mathrm{e}$ & $20.9 \mathrm{~d}$ \\
\hline \multicolumn{8}{|c|}{ Location } \\
\hline Jelenia Góra & $51.8 \mathrm{~b}$ & $40.2 \mathrm{a}$ & $20.6 \mathrm{a}$ & $55.1 \mathrm{a}$ & $21.7 \mathrm{~b}$ & $2.6 \mathrm{~b}$ & $23.8 \mathrm{a}$ \\
\hline Bobrowniki & $53.4 \mathrm{a}$ & $37.8 \mathrm{~b}$ & $21.5 \mathrm{a}$ & $42.5 \mathrm{~b}$ & $31.5 \mathrm{a}$ & $4.5 \mathrm{a}$ & $23.4 \mathrm{a}$ \\
\hline \multicolumn{8}{|c|}{ Years } \\
\hline 1997 & $51.5 \mathrm{~b}$ & $40.1 \mathrm{a}$ & $21.0 \mathrm{a}$ & $55.1 \mathrm{a}$ & $22.1 \mathrm{~b}$ & $1.8 \mathrm{~b}$ & $23.8 \mathrm{a}$ \\
\hline 1998 & $53.7 \mathrm{a}$ & $37.9 \mathrm{~b}$ & $21.1 \mathrm{a}$ & $42.5 \mathrm{~b}$ & $31.1 \mathrm{a}$ & $5.3 \mathrm{a}$ & $23.3 \mathrm{a}$ \\
\hline
\end{tabular}

a, b, c, d, e- means indicated by the same letter do not differ significantly at $\mathrm{P} \geq 0.95$

nel and groat weight, groat percentage, ash, starch, protein, lipid, $\beta$-glucan, tocopherol, tocotrienol and avenanthramide content.

A major factor determining the quality of cereals and their suitability for agricultural applications and processing is the hectoliter weight (Forsberg and Reeves 1992), which in the oat grain under investigation was found within the range of $50.6 \mathrm{~kg} \cdot \times \mathrm{hl}^{-1}$ (Skrzat cultivar) to $54.1 \mathrm{~kg} \times \mathrm{hl}^{-1}$ (Bajka cultivar), but the differences were insignificant (Table 3 ). Oat with such parameters is suitable for processing by all means. The qualitative tests of the oat grain from consecutive harvest years and different locations showed that average hectoliter weight of the grain harvested in 1998 was higher than that of the grain harvested in 1997. Nevertheless, the oat harvested in Bobrowniki exhibited higher parameters than that from Jelenia Góra. Similar conclusions were reported by Gąsiorowski et al. (1997 a), while Lapveteläinen et al. (2001) reported higher hectoliter weight of oat grain. Oat grain destined for processing should exhibit a high 1000-kernel weight. In Germany, it is within the range of 24.9 to $34.0 \mathrm{~g}$ (Hampshire et al. 1998). 
The range reported by Lapveteläinen et al. (2001) was smaller, i.e. within 30.7-37.5 g. The oat cultivars tested by Czubaszek (2003) and those under investigation in the present study exhibited higher 1000-kernel weight. The greatest differences were found between the cultivars of Sławko (44.6 g) and Góral, Skrzat and Jawor (36.0, 36.5 and 36.9 g, respectively) (Table 3). High values were also noted in case the Bajka cultivars (42.3 g), German $(40.4 \mathrm{~g})$ and Dragon $(39.1 \mathrm{~g})$. Moreover, it was found that due to the weather conditions prevailing in Jelenia Góra, the oat grain harvested there were better developed as compared to those harvested in Bobrowniki, with similar relationship found between the samples collected in 1997 in comparison with 1998.

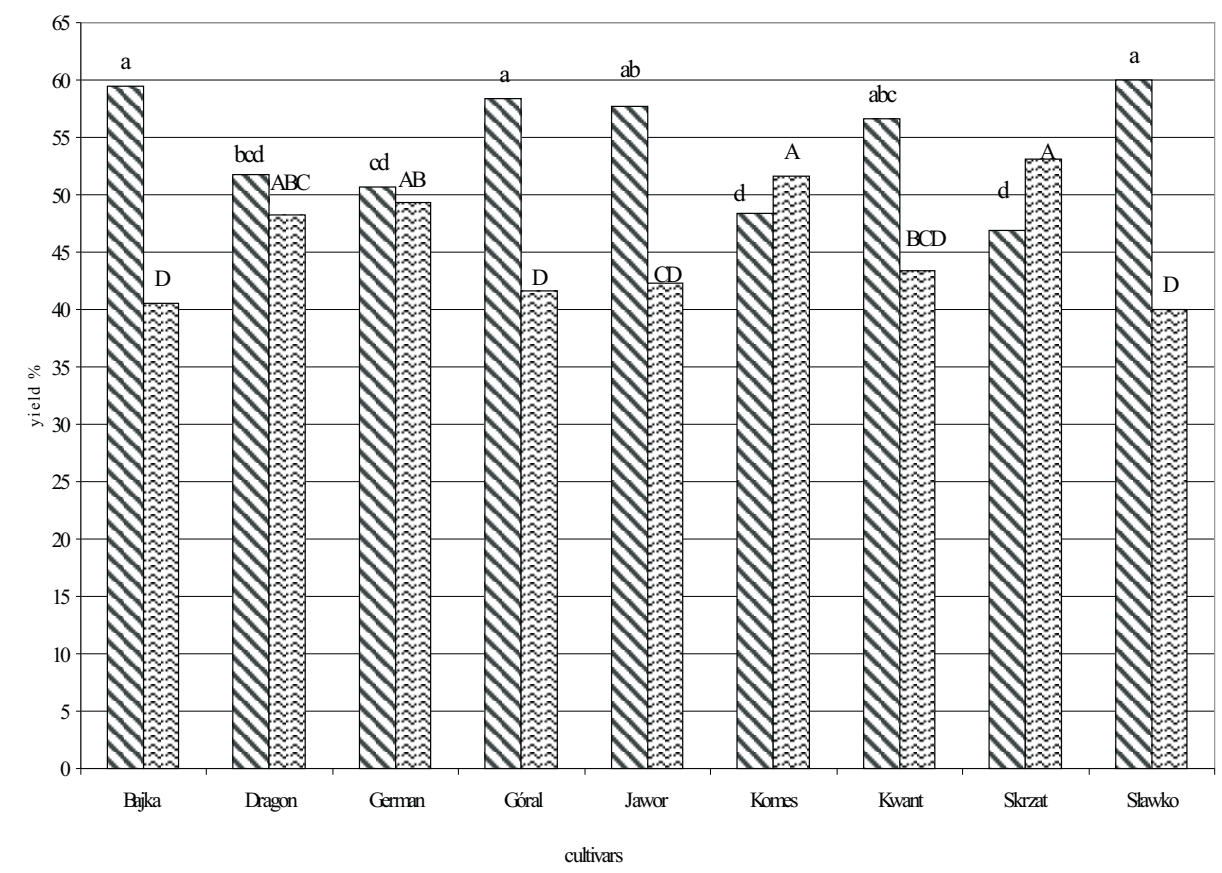

\$ flour yield $\mathrm{E}$ bran yield

Fig. 2. Yield of flour and bran from grain of oat cultivars. Capital and small letter - means indicated by the same letter do not differ significantly at $\mathrm{P} \geq 0.95$

The technological value of oat grain is considered appropriate when its size and shape is well-developed and when it looks healthy. It should not contain more than $10 \%$ of grain below $2.2 \mathrm{~mm}$ in thickness (Hampshire et al. 1998, Gleń 2004). All the cultivars under investigation met this requirement. The percentages of grain exhibiting the thickness below $2.2 \mathrm{~mm}$ 
ranged from $1.1 \%$ (Sławko) to $7.4 \%$ (Komes) (Table 3). The cultivar of Sławko was the best in appearance and it had the highest percentage $(43.2 \%)$ of grain, sized $>2.8 \mathrm{~mm}$ in thickness. Also the cultivars of Dragon, Bajka, Skrzat, Kwant, German and Jawor contained considerable number of fractions within the thickness range between 2.5-2.8 mm. Oat grain of Komes cultivar was the smallest in size. On average, the oat grain from Jelenia Góra was larger in size than that from Bobrowniki, and that harvested in 1997 looked better than the one harvested in 1998.

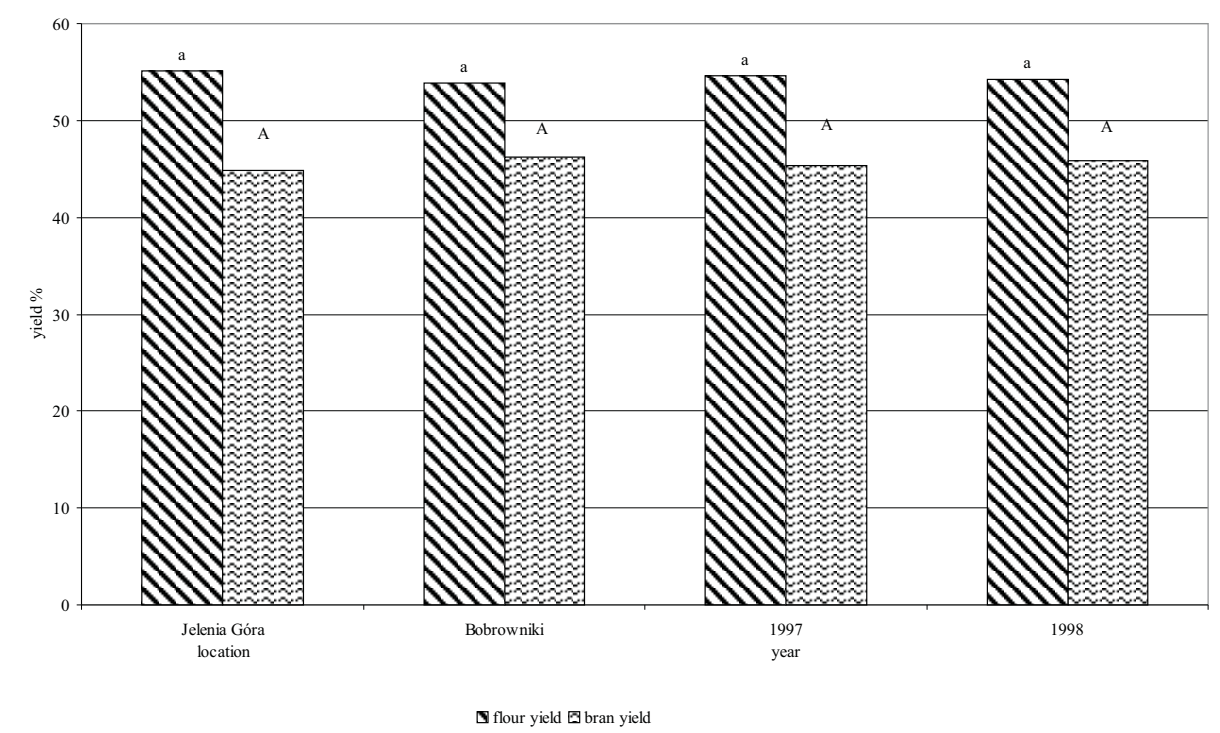

Fig. 3. Yield of flour and bran from samples of grain harvested in different localities and years. Capital and small letter - means indicated by the same letter do not differ significantly at $\mathrm{P} \geq 0.95$

The hull of the kernel reduces digestibility of oat and also its nutritive and technological values. Oat grain with high hull content is not suitable for processing. For this reason, attempts in breeding have been made to reduce the hull content to the minimum. According to Hampshire et al. (1998), the hull content of oat destined for processing should not exceed $26 \%$. The results obtained in the present study show that all the oat cultivars under investigation met the requirements. The lowest hull content $(20.9 \%)$ was found in the cultivar of Sławko and the next was Kwant (22.0\%) (Table 3). A higher percentage $(25.8 \%)$ was found in the cultivars of Komes and Góral. Present work indicates that the hull content depends on the cultivar and does not depend on growing conditions, because non-significant differences in hull content were found in the samples collected from the two locations in the two years of present investigation. 
Total protein content, proteolytic activity and falling number in grain and flour of oat for cultivar, location and years

\begin{tabular}{|c|c|c|c|c|c|c|}
\hline \multirow[b]{2}{*}{$\downarrow$ Factor } & \multicolumn{2}{|c|}{ Total protein content [\%] } & \multicolumn{2}{|c|}{ Proteolytic activity [units] } & \multicolumn{2}{|c|}{ Falling number $[\mathrm{s}]$} \\
\hline & Grain & Flour & Grain & Flour & Grain & Flour \\
\hline \multicolumn{7}{|c|}{ Cultivars } \\
\hline Bajka & $13.8 \mathrm{de}$ & $10.0 \mathrm{a}$ & $3.92 \mathrm{a}$ & $3.49 \mathrm{a}$ & $344 \mathrm{a}$ & $373 \mathrm{a}$ \\
\hline Dragon & $15.5 \mathrm{a}$ & $11.1 \mathrm{a}$ & $3.39 \mathrm{a}$ & $3.47 \mathrm{a}$ & $345 \mathrm{a}$ & $377 \mathrm{a}$ \\
\hline German & $14.8 \mathrm{~b}$ & $10.8 \mathrm{a}$ & $3.40 \mathrm{a}$ & $3.35 \mathrm{a}$ & $381 \mathrm{a}$ & $417 \mathrm{a}$ \\
\hline Góral & 14.2 bcde & $10.4 \mathrm{a}$ & $4.37 \mathrm{a}$ & $3.66 \mathrm{a}$ & $394 \mathrm{a}$ & $388 \mathrm{a}$ \\
\hline Jawor & $14.4 \mathrm{bcd}$ & $10.8 \mathrm{a}$ & $3.60 \mathrm{a}$ & $3.30 \mathrm{a}$ & $328 \mathrm{a}$ & $409 \mathrm{a}$ \\
\hline Komes & $14.6 \mathrm{bc}$ & $11.2 \mathrm{a}$ & $3.56 \mathrm{a}$ & $3.52 \mathrm{a}$ & $360 \mathrm{a}$ & $376 \mathrm{a}$ \\
\hline Kwant & $14.1 \mathrm{cde}$ & $10.2 \mathrm{a}$ & $4.00 \mathrm{a}$ & $3.06 \mathrm{a}$ & $339 a$ & $372 \mathrm{a}$ \\
\hline Skrzat & $14.3 \mathrm{bcd}$ & $10.5 \mathrm{a}$ & $3.90 \mathrm{a}$ & $3.24 \mathrm{a}$ & $376 \mathrm{a}$ & 393 a \\
\hline Sławko & $13.6 \mathrm{e}$ & $10.0 \mathrm{a}$ & $3.65 \mathrm{a}$ & $3.04 \mathrm{a}$ & $383 \mathrm{a}$ & $425 \mathrm{a}$ \\
\hline \multicolumn{7}{|c|}{ Location } \\
\hline Jelenia Góra & $14.1 \mathrm{~b}$ & $10.4 \mathrm{a}$ & $3.79 \mathrm{a}$ & $3.45 \mathrm{a}$ & $338 \mathrm{~b}$ & $391 \mathrm{a}$ \\
\hline Bobrowniki & $14.6 \mathrm{a}$ & $10.7 \mathrm{a}$ & $3.71 \mathrm{a}$ & $3.24 \mathrm{a}$ & $384 \mathrm{a}$ & $394 \mathrm{a}$ \\
\hline \multicolumn{7}{|c|}{ Years } \\
\hline 1997 & $15.3 \mathrm{a}$ & $11.1 \mathrm{a}$ & $3.46 \mathrm{a}$ & $3.71 \mathrm{a}$ & $321 \mathrm{~b}$ & $362 \mathrm{~b}$ \\
\hline 1998 & $13.4 \mathrm{~b}$ & $10.0 \mathrm{~b}$ & $4.05 \mathrm{a}$ & $2.98 \mathrm{~b}$ & $401 \mathrm{a}$ & $422 \mathrm{a}$ \\
\hline
\end{tabular}

$a, b, c, d, e-$ means indicated by the same letter do not differ significantly at $P \geq 0.95$

Fig. 2. shows that milling properties varied depending on the oat cultivar. High flour yield was found in the cultivars of Sławko $(60.0 \%)$, Bajka (59.4\%), Góral (58.4\%), Jawor (57.7\%) and Kwant (56.6\%). The highest yield of oat bran was observed with the cultivars of Skrzat $(53.1 \%)$ and Komes (51.6\%). No differences in the mean flour and bran yields were observed between the samples collected in Jelenia Góra and Bobrowniki and in the harvest years 1997 and 1998 (Fig. 3). Doehlert and McMullen (2000) used the Quadrumat Junior mill for oat milling and a sieve with a mesh of $0.25 \mathrm{~mm}$. In this way, they obtained higher yield of oat flour and lower yield of bran as compared to the results obtained in the present study. The above-mentioned authors reported impact of genetic and environmental factor on yield of flour and bran. They also indicated negative correlation between oat bran yield vs. hectoliter weight and groat oat weight. On the other hand, they reported a positive correlation with grain hardness.

According to Gąsiorowski et al. (1997 b), in Poland where the climate is moderate, no significant impact of weather conditions on protein content of oat grain can be expected. However, the results reported by Walens (2003) 
show that oat grain harvested in the years with higher precipitation levels was lower in protein than that harvested in dry years. Table 4 . shows that the samples collected in Bobrowniki, where precipitation level was lower than in Jelenia Góra, were higher in total protein. Moreover, it was found that both grain and flour of the samples collected in 1997 were higher in protein, as compared to the samples collected in 1998. The highest protein content $(15.5 \%)$ was found in the cultivar of Dragon, and next were the cultivars of German, Komes, Jawor, Skrzat and Góral. The cultivars of Sławko and Bajka exhibited the lowest protein content $(13.6 \%$ and $13.8 \%$, respectively). Oat flour, similarly as in the studies carried out by Doehlert and McMullen (2000), contained less protein than oat grain, but the flour obtained from various cultivars did not show any significant differences in protein content, which ranged from $10.0 \%$ to $11.2 \%$.

Proteolytic enzymes cause degradation of reserve proteins present in cereals, which reduces the technological value of grain, therefore it is important to determine their proteolytic activity (Dojczew and Sobczyk 2007, Piasecka-Kwiatkowska et al. 2007). The data in literature (Czubaszek 2003, Subda et al. 1998 a,b) show that proteolytic activity of oat grain ranges from 2.64 to 5.48 units. The average proteolytic activity of wheat flour usage for the bread bakery purposes is located at the level of 1.38-3.20 unit (Żmijewski et al. 1999, Subda et al. 2002). Comparing proteolytic activity of oat with the results obtained for the wheat it can be concluded that proteolytic activity level of oat grain is higher than the wheat flour, and as such it can become significant factor while using oat flour in bakery. According to Dojczew et al. (2004) the highest level of proteolytic activity is the cause of changes in solubility of prolamines and glutelins fractions and negatively influences the rheological properties of the dough and the bread quality. As can be seen in Table 4, the material under investigation exhibited average proteolytic activity, ranging from 3.39 to 4.37 units. No differences cultivar-related were observed. Also, neither the location of the trials nor the years of harvest affected the proteolytic activity, however, it was $1-26 \%$ lower in oat flour than in oat grain. The differences were also noticed between the flour samples obtained from oat harvested in 1997 and 1998 (3.71 and 2.98, respectively).

The activity of amylolytic enzymes present in wheat and rye is determined with regard to the falling number. Kaarlehto and Salovaara (2000) and Doehlert and McMullen (2003) report that Hagberg-Perten's method can also be used with oat products, but the values obtained with oat are higher than those obtained with wheat. The cause of higher falling number in oat products than in case of wheat flour might be higher temperature of gelatinization in oat products in comparison with wheat ones (Wang and White 1994, Doehlert et. al.1997). It has been also established that amylases activity level in oat is lower than in wheat (Meredith and Jenkins 1973), and the oat starch in comparison with the wheat one is less prone to 
the activity of this enzyme (Tester and Karkalas 1996). The falling number of oat is usually found within the range of 300-600s (Kaarlehto and Salovaara 2000). When Polish oat cultivars were studied (Czubaszek 2003, 2006), the results were found within the same range. Similar results have been reached in presented studies (Table 4). Oat cultivars did not affect the falling number of grain or flour, which ranged from $328 \mathrm{~s}$ (Jawor cultivar) to $394 \mathrm{~s}$ (Góral cultivar), while that of flour ranged from $377 \mathrm{~s}$ (Bajka cultivar) to $425 \mathrm{~s}$ (Sławko cultivar). On average, the falling number of grain samples collected in Jelenia Góra was lower than that of the samples collected in Bobrowniki, but the flour made of oat grain grown in the two locations did not show any differences in the falling number. Both the oat grain and the flour samples collected in 1998 exhibited higher falling number than those collected in 1997. It was probably caused by heavy rainfalls in Jelenia Góra in 1997. Moreover, significant $(\mathrm{P} \geq 0.95$ and $n=36)$ relation between the falling number and both soluble and insoluble pentosans contents was reported. The correlations of linear, regular coefficient reached respectively 0.32 and 0.54 (data not included).

Starch is the predominant carbohydrate in cereals. The content of this polysaccharide in oat grain ranges from 39.3 to $67.5 \%$ (Lapveteläinen et al. 2001, Doehlert and McMullen 2000, Rhymer et al. 2005, Czubaszek 2003, Subda et al. 1998 a,b, Wilhelmson et al. 2001, Colleoni-Sirghie et al. 2004). After milling, the content of this ingredient in oat flour is higher (56.4-73.9\%) than in oat grain (Doehlert and McMullen 2000, Wood et al. 2002). In this study starch content in the oat cultivars ranged from $46.4 \%$ (German) to $51.7 \%$ (Sławko), but the differences were insignificant (Table 5). The starch content of the samples collected in Jelenia Góra was $6 \%$ higher than that of the samples collected in Bobrowniki. Oat flour contained more starch than oat grain and no impact of the genetic factor was observed. However, the impact of the environmental factor (location and harvest year) was obvious. Higher starch content was found in the samples collected in Bobrowniki and those collected in 1997.

Pentosans present in Polish cultivars of oats are found within the range of 3.74 to $4.38 \%$ (Czubaszek 2003, Subda et al. 1998 a,b). Lower quantities $(1.8-2.8 \%)$ have been found in American and Finnish cultivars (Wilhelmson et al. 2001, Colleoni-Sirghie et al. 2004). Such differences between the oat cultivated in Poland and the American or Finnish cultivars may constitute the result of diverse traits of the oat grain cultivated in these countries. Nevertheless, it may also be caused by the fact of applying various methods of determining pentosans by the abovementioned authors. Total pentosans content of the material taken for our studies ranged from 3.56 to $4.13 \%$ (Table 5). The content of insoluble pentosans was high, but soluble ones constituted only $7 \%$ of total pentosans. No differences in the content of these compounds were observed between the cultivars, but the effects of environmental factors were obvious. The samples from different 
Table 5.

Starch and pentosans content in grain and flour of oat for cultivar, location and years

\begin{tabular}{|c|c|c|c|c|c|c|c|c|}
\hline \multirow{3}{*}{$\begin{array}{l}\text { Trait } \rightarrow \\
\text { tor }\end{array}$} & \multirow{2}{*}{\multicolumn{2}{|c|}{ Starch content $[\%]$}} & \multicolumn{6}{|c|}{ Pentosans content $[\%]$} \\
\hline & & & \multicolumn{2}{|c|}{ Soluble } & \multicolumn{2}{|c|}{ Unsoluble } & \multicolumn{2}{|c|}{ Total } \\
\hline & Grain & Flour & Grain & Flour & Grain & Flour & Grain & Flour \\
\hline \multicolumn{9}{|c|}{ Cultivars } \\
\hline Bajka & $49.9 \mathrm{a}$ & $56.7 \mathrm{a}$ & $0.25 \mathrm{a}$ & $0.11 \mathrm{a}$ & $3.33 \mathrm{a}$ & $1.14 \mathrm{a}$ & $3.58 \mathrm{a}$ & $1.25 \mathrm{a}$ \\
\hline Dragon & $48.5 \mathrm{a}$ & $54.1 \mathrm{a}$ & $0.23 \mathrm{a}$ & $0.14 \mathrm{a}$ & $3.62 \mathrm{a}$ & $1.29 \mathrm{a}$ & $3.85 \mathrm{a}$ & $1.43 \mathrm{a}$ \\
\hline German & $46.4 \mathrm{a}$ & $55.0 \mathrm{a}$ & $0.29 \mathrm{a}$ & $0.10 \mathrm{a}$ & $3.38 \mathrm{a}$ & $1.14 \mathrm{a}$ & $3.67 \mathrm{a}$ & $1.24 \mathrm{a}$ \\
\hline Góral & $48.3 \mathrm{a}$ & $57.3 \mathrm{a}$ & $0.22 \mathrm{a}$ & $0.15 \mathrm{a}$ & $3.55 \mathrm{a}$ & $1.23 \mathrm{a}$ & $3.78 \mathrm{a}$ & $1.38 \mathrm{a}$ \\
\hline Jawor & $48.3 \mathrm{a}$ & $57.7 \mathrm{a}$ & $0.25 \mathrm{a}$ & $0.11 \mathrm{a}$ & $3.65 \mathrm{a}$ & $1.23 \mathrm{a}$ & $3.90 \mathrm{a}$ & $1.34 \mathrm{a}$ \\
\hline Komes & $50.9 \mathrm{a}$ & $53.9 \mathrm{a}$ & $0.23 \mathrm{a}$ & $0.11 \mathrm{a}$ & $3.44 \mathrm{a}$ & $1.26 \mathrm{a}$ & $3.67 \mathrm{a}$ & $1.37 \mathrm{a}$ \\
\hline Kwant & $47.4 \mathrm{a}$ & $55.4 \mathrm{a}$ & $0.25 \mathrm{a}$ & $0.11 \mathrm{a}$ & $3.88 \mathrm{a}$ & $1.26 \mathrm{a}$ & $4.13 \mathrm{a}$ & $1.37 \mathrm{a}$ \\
\hline Skrzat & $50.0 \mathrm{a}$ & $55.2 \mathrm{a}$ & $0.25 \mathrm{a}$ & $0.12 \mathrm{a}$ & $3.49 \mathrm{a}$ & $1.24 \mathrm{a}$ & $3.74 \mathrm{a}$ & $1.36 \mathrm{a}$ \\
\hline Sławko & $51.7 \mathrm{a}$ & $58.4 \mathrm{a}$ & $0.26 \mathrm{a}$ & $0.11 \mathrm{a}$ & $3.31 \mathrm{a}$ & $1.09 \mathrm{a}$ & $3.56 \mathrm{a}$ & $1.20 \mathrm{a}$ \\
\hline \multicolumn{9}{|c|}{ Locations } \\
\hline Jelenia Góra & $52.1 \mathrm{a}$ & $54.5 \mathrm{~b}$ & $0.25 \mathrm{a}$ & $0.10 \mathrm{~b}$ & $3.63 \mathrm{a}$ & $1.22 \mathrm{a}$ & $3.88 \mathrm{a}$ & $1.32 \mathrm{a}$ \\
\hline Bobrowniki & $46.0 \mathrm{~b}$ & $57.4 \mathrm{a}$ & $0.25 \mathrm{a}$ & $0.14 \mathrm{a}$ & $3.40 \mathrm{~b}$ & $1.20 \mathrm{a}$ & $3.65 \mathrm{~b}$ & $1.34 \mathrm{a}$ \\
\hline \multicolumn{9}{|c|}{ Years } \\
\hline 1997 & $48.1 \mathrm{a}$ & $60.0 \mathrm{a}$ & $0.22 \mathrm{~b}$ & $0.14 \mathrm{a}$ & $3.07 \mathrm{~b}$ & $1.46 \mathrm{a}$ & $3.29 \mathrm{~b}$ & $1.60 \mathrm{a}$ \\
\hline 1998 & $50.0 \mathrm{a}$ & $51.8 \mathrm{~b}$ & $0.27 \mathrm{a}$ & $0.09 \mathrm{~b}$ & $3.97 \mathrm{a}$ & $0.96 \mathrm{~b}$ & $4.24 \mathrm{a}$ & $1.05 \mathrm{~b}$ \\
\hline
\end{tabular}

$\mathrm{a}, \mathrm{b}, \mathrm{c}, \mathrm{d}, \mathrm{e}-$ means indicated by the same letter do not differ significantly at $\mathrm{P} \geq 0.95$

locations and harvest years varied in the content of pentosans. The content of soluble pentosans was exclusively harvest year- related.

Michniewicz et al. (1998) found that oat flour was about $60 \%$ lower in pentosans than oat grain. Similar results were obtained in our investigations (Table 5). The percentages of soluble and insoluble fractions found in total pentosans of oat flour were similar to those found in oat grain. Oat grain, obtained from different cultivars, contained $1.20-1.38 \%$ of total pentosans, $1.09-1.29 \%$ of insoluble pentosans and $0.10-0.15 \%$ of soluble pentosans. The content of soluble pentosans varied, depending on the location in which the samples were taken and the harvest year. The flour produced from oat grain harvested in Bobrowniki and in the year 1997 was higher in soluble pentosans. Insoluble and total pentosans content of the flour produced from oat grain harvested in 1997 was higher than that from grain harvested in 1998. 


\section{CONCLUSIONS}

It has been confirmed that physical traits of oat grain as well as flour and bran yields were primarily genotype-related. The environmental factors affected the hectoliter weight, 1000-kernel weight and percentages of grain exhibiting significant differences in thickness. The location-harvest year interactions had an impact on the hectoliter weight, 1000-kernel weight, hull content and percentages of oat grain of 2.2-2.5 mm in thickness. Suitability of oat grain for processing was determined with regard to the hectoliter weight, 1000-kernel weight, percentages of grain $<2.2 \mathrm{~mm}$ in thickness and hull content and it was reported that the oat tested met these requirements.

The chemical composition of oat grain was dependent on environmental factors. Only the total protein content varied, depending on cultivars and their interactions with the location of production. The interactions between location and harvest year influenced the content of total protein, insoluble and total pentosans. All the oat cultivars were high in total protein, but low in starch. The activity of proteolytic and amylolytic enzymes was on average levels. Total pentosans were high in insoluble, but low in soluble pentosans.

Apart from the participation of grain $2.2-2.5 \mathrm{~mm}$ thick and total protein content, the physical and chemical traits of oat grain was not influenced by the variability of interactions cultivar - location and cultivar - year. It indicates considerable stability of the traits of the tested cultivars in various environmental conditions.

The yield of flour and bran of oat cultivars varied significantly. High level of yield of flour was reported in case of the Bajka, Góral, Jawor, Kwant i Sławko cultivars. Skrzat and Komes cultivars reported higher yield of bran than flour. All the flour from the examined oat cultivars was of similar chemical composition. Only in case of the starch and soluble pentosans contents the flour made of grain from Jelenia Góra and Bobrowniki exhibited differences, with bigger amount of such ingredients from Bobrowniki sample. The weather conditions during the plants growth in 1997 and 1998 diversified the contents of chemical compounds examined in oat flour.

\section{REFERENCES}

Colleoni-Sirghie M., Jannink J.-L., Kovalenko I.V., Briggs J.L., White P.J. 2004. Prediction of $\beta$-glucan concentration based on viscosity evaluations of raw oat flours from high $\beta$-glucan and traditional oats lines. Cereal Chem. 81(4), 434-443.

Czubaszek A. 2003. Wybrane cechy fizyczne i skład chemiczny ziarna kilku odmian owsa. Biul. IHAR, $229,307-315$.

Czubaszek A. 2006. Ocena właściwości reologicznych ciasta i jakości chleba pszennego z dodatkiem owsa. Biul. IHAR, 239, 247-257.

Doehlert D.C., McMullen M.S. 2000. Genotypic and environmental effect on oat milling characteristics and groat hardness. Cereal Chem. 77, 148-154.

Doehlert D.C., McMullen M.S., Hammond J.J. 2001. Genotypic and environmental effects on grain yield and quality of oat grown in North Dakota. Crop Sci. 41, 1066-1072. 
Doehlert D.C., McMullen M.S. 2003. Identyfication of sprout damage in oats. Cereal Chem. 80(5), 608-612.

Doehlert D.C., Zhang D., Moore W.R. 1997. Influence of heat pretreatments of oat grain on the viscosity of flour slurries. J. Sci. Food Agric. 74, 125-131.

Dojczew D., Sobczyk M. 2007. The effect of proteolytic activity on the technological value of wheat flour from pre-harvest sprouted grain. Acta Scientiarum Polonorum, Technologia Alimentaria, 64(4): 45-54.

Dojczew D., Sobczyk M., Grodzicki K., Haber T. 2004. Wpływ porostu ziarna na wartość wypiekową mąki pszennej, pszenżytniej i żytniej. Acta Sci. Pol. Technologia Alimentaria 3(2) 127-136.

Forsberg R.A., Reeves D.L. 1992. Breeding oat cultivars for improved grain quality. W: Oat science and technology. H.G. Marshall, M.E. Sorrells (ed.). ASA and CSSa, Madison WI., 751-775.

Gąsiorowski H., Klockiewicz-Kamińska E., Chalcarz A., Górecka D. 1997 a. Charakterystyka polskiego owsa (cz.2). Technologiczne wskaźniki jakości polskiego owsa. Prz. Zboż.-Młyn. 5, 42.

Gąsiorowski H., Klockiewicz-Kamińska E., Chalcarz A., Górecka D. 1997 b. Charakterystyka polskiego owsa (cz.1). Prz. Zboż. Młyn. 4, 23-27.

Gleń A. 2004. Dobór odmiany a wartość technologiczna ziarna owsa. Prz. Zboż. Młyn. 10, 9-10.

GUS 2009. Mały Rocznik Statystyczny Polska 2009. Zakład Wydawnictw Statystycznych. Warszawa Rok LII, ISSN 1640-3630.

Hampshire J., Ganâmann W., Meyer D. 1998. Qualität der Haferernte 1997 - Untersuchungen an Hafersorten und Industriehafer. Getreide Mehl u. Brot, 4, 197-201.

Kaarlehto T., Salovaara H. 2000. Effect of dry-kiln drying on falling number of oats. Cereal Chem. $77(2), 177-180$

Konopka I., Fornal Ł., Abramczyk D., Rothkaehl J., Rotkiewicz D. 2004. Statistical evaluation of different technological and rheological tests of Polish wheat varieties for bread volume prediction. Int. J. Food Sci., 39, 11-20.

Lapveteläinen A., Alho-Lehto P., Sinn L., Laukkanen T., Lindman T., Kallio H., Kataranta J., Katajisto J. 2001. Relationship of selected physical and chemical, and sensory parameters in oat grain, rolled oats, and cooked oatmeahl - a three year study with eight cultivars. Cereal Chem. 78(3), 322-329.

Lue S., Hsieh F., Huff H.E. 1991. Estimation cooking of corn meal and sugar beet fiber: effects on expansion properties, starch gelatinization and dietary fiber content. Cereal Chem., 68, 227-234.

Ma C.-Y. 1983. Chemical characterization and functionality assessment of protein concentrates from oats. Cereal Chem. 60, 36-42.

Meredith P., Jenkins L.D. 1973. Amylases of developing wheat, barley, and oat grains. Cereal Chem. $50(3), 243-254$

Michniewicz J. 1995. Pentozany w technologii zbóż. Rocz. AR w Poznaniu. Rozprawy Nauk. Zesz. 261.

Michniewicz J., Kołodziejczyk P., Nadolna J., Anioła J., Ulichnowska L. 1998. Ocena zawartości różnych form nieskrobiowych polisacharydów. Prz. Zboż. Młyn. 5, 14-17.

Ötles S., Cagindi Ö. 2006. Cereal based functional foods and nutraceuticals. Acta Scientiarum Polonorum, Technologia Alimentaraia, 5(1):107-112.

Peltonen-Sainio P., Topi-Hulmi M. (eds.). 2004. Proceedings $7^{\text {th }}$ International Oat Conference. Helsinki, Finland. Jokioinen: MTT Agrifood Research Finland. Agrifood Research Reports 51.

Peterson D.M., Wesenberg D.M., Burrup D.E., Erickson C.A. 2005. Relationship among agronomic traits and grain composition in oat genotypes grown in different environments. Crop Sci. 45(4), 1249-1255.

Piasecka-KwiatkowskaD., Madaj D., Warchalewski J.R. 2007. The biological activity of wheat, rye and triticale varietes harvested In four consecutive years. Acta Scientiarum Polonorum, Technologia Alimentaria, 5(1): 55-66.

PN-ISO 3093:1996. Zboża. Oznaczanie liczby opadania. Wyd. Normal., Warszawa

PN-ISO 7971-2:1998. Ziarno zbóż. Oznaczanie gęstości w stanie zsypnym, zwanej „masą hektolitra”. Wyd. Normal., Warszawa.

Rhymer C., Ames N., Malcolmson L., Brown D., Duguid S. 2005. Effects of genotype and environment on the starch properties and end-product quality of oats. Cereal Chem. 82(2), 197-203.

Subda H. 1984 a. Instrukcja wdrożeniowa oznaczania aktywności enzymów proteolitycznych. Biul. IHAR, $155,139-141$.

Subda H.1984 b. Metoda oznaczania zawartości pentozanów rozpuszczalnych w wodzie (Instrukcja). Biul IHAR 155, 225-226.

Subda H., Karolini-Skaradzińska Z., Czubaszek A. 1998 a. Skład chemiczny i wartość technologiczna wybranych odmian owsa. Biul. IHAR 208, 111-122.

Subda H., Karolini-Skaradzińska Z., Czubaszek A., Gil Z. 1998 b. Skład chemiczny kilku polskich odmian owsa. Biul. IHAR 208, 103-109.

Subda H., Jarosławska A., Anton A., Karolini-Skaradzińska Z. 2002. Ocena wpływu wybranych cech chemicznych pszenicy ozimej na jakość ciasta i chleba. Biul. IHAR, 223/224, 111-119.

Sułek A., Leszczyńska D., Zych J. 2001. Charakterystyka i wymagania agrotechniczne odmian owsa. Wyd. IHAR Radzików. 
Tester R.F., Karkalas J. 1996. Swelling and gelatinization of oat starches. Cereal Chem. 73(2), 271-277.

Wang L.Z., White P.J. 1994. Functional properties of oat starches and relationship among functional and structural characteristics. Cereal Chem. 71, 451-458.

Walens M. 2003. Wpływ nawożenia azotowego i gęstości siewu na wysokość i jakość plonu ziarna odmian owsa oplewionego i nagoziarnistego. Biul. IHAR 229, 115-124.

Wilhelmson A., Oksman-Caldentey K.-M., Laitila A., Suortti T., Kaukovirta-Norja A., Poutanen K. 2001. Development of a germination process for producing high $\beta$-glucan, whole grain food ingredients from oat. Cereal Chem. 78(6), 715-720.

Wood P.J., Arrigoni E., Miller S.S., Amadó R. 2002. Fermentability of oat and wheat fractions enriched in $\beta$-glucan using human fecal inoculation. Cereal Chem. 79(3), 445-454.

Żmijewski M., Subda H., Korczak B., Kowalska M., Karolini-Skaradzińska Z., Czubaszek A. 1999.Skład chemiczny i wartość wypiekowa ziarna oraz maki odmian pszenicy jarej. Część I. Skład chemiczny. Biul. IHAR, 212, 65-70. 